\title{
The Effects of Frying Time and Temperatures on Fatty Acids Profile of Blanched Potato Chips
}

\author{
Addion Nizori ${ }^{*}$ and Vijay Mishra ${ }^{\#}$ \\ Technology of Agricultural Product Department, Universitas Jambi, Indonesia \\ \# School of Biomedical and Health Sciences, Victoria University, \\ Werribee campus, P.O. Box 14428, Melbourne, Vic., 8001 Australia \\ Corresponding author: addion_nizori@unja.ac.id
}

\begin{abstract}
The aim of this research was to study whether the frying time and temperature affected fatty acids profiles of blanched potato chips. Factorial designs were carried out using a completely randomized design (CRD) two factor (time and temperature) and three levels with two replications. Frying temperature was set up at $160{ }^{\circ} \mathrm{C}, 180^{\circ} \mathrm{C}$ and $200{ }^{\circ} \mathrm{C}$. The potato chips were fried for $3,5,7$ minutes. The oil type used was sunflower. The fatty acids profiles were analyses with capillary gas liquid chromatography (Varian 3400) equipped with an auto sampler and a flame ionization detector (FID) using a $50 \mathrm{~m} \times 0.32 \mathrm{~mm}$ (I.D) fused silica bonded phase capillary column (BPX70, SGE, Melbourne, Australia). The experiments were run in duplicate and the present results are the average of the obtained values. ANOVA analysis of the results was carried out using SPSS software (version 11, 2004). The key plot software for making three dimensions was the sigma plot scientific graphing software. The results showed moisture content and colour index of blanched potato chips decreased significantly with increasing frying time and temperature. Furthermore, unsaturated fatty acids (cis oleic and linoleic) decrease after long period frying.
\end{abstract}

Keywords - Frying, time, temperature, fatty acids

\section{INTRODUCTION}

One of the most popular cooking methods world-wide is deep-frying. Several studies comparing performances of different vegetable oils during prolonged frying have been carried out by many reseearches [1].

During the frying process, the physical, chemical and sensory characteristics of the food are modified. Texture, colour and oil content are the main quality of the fried foods. Fried food with low oil content are preferred. Excessive fat adsorbed by food can reduces the organoleptic qualities of the fried food [2]. Most of food nutrition are loss by evaporation or leaching, while some new compounds are formed during these hot oil-food interactions, including highly pleasant ones, as the typical fried volatile flavors, or unhealthy ones, as degraded lipids and acrylamide formed [3].

Potato rich in some micronutrients, as important minerals, carotenoids, phenolic compounds, and vitamin C [4]. However, to increasing its digestibility for human, potatoes are consumed only after food processing ; cooking, boiling, roasting and frying [5]. Health impact of saturated fats is still arguing, and hydrogenated ones are fading out, vegetable unsaturated fats have moved to the forefront, and among them, monounsaturated fats (MUFA) are increasingly supporting a broader spectrum of functionality and health claims in many countries [6].

Therefore This present work was conduct to investigate the effect of frying time and temperature on fatty acids profiles, moisture content, fat uptake, moisture loss, colour, texture of blanched potato chips.

\section{MATERIAL AND MEthodS}

\section{A. Chemicals}

$2 \mathrm{M} \mathrm{KOH}$ in methanol, $2 \mathrm{M} \mathrm{HCL}$ containing methyl orange indicator, methanol, boron trifuoride and petroleum ether.

\section{B. Sample Preparations}

Fresh Potato and sunflower oil obtained from safeway supermarket Hoppers crossing Melbourne. Breville, deep fryer, digital thermometer (calibrated) kenwood high speed slicer and shredder (blade no2). A small- 
scale commercial deep fat fryer (Breville) was with temperature control used. The fryer was filled with $2 \mathrm{~L}$ oil and ratio was kept at 1:20 (200g chips in $2 \mathrm{~L}$ oil) $\mathrm{w} / \mathrm{v}$. Sample were placed in wire basket to ensure good contact between the chips and oil.

Frying temperature was set up at 160 ${ }^{0} \mathrm{C}, 180{ }^{\circ} \mathrm{C}$ and $200{ }^{\circ} \mathrm{C}$. The potato chips were fried for 3, 5, 7 minutes. The fried chips will remove from the oil and turned on adsorbent paper. The oil type used was sunflower. The chips were treated in $0.3 \%$ sodium metabisulphite dip and excess moisture was removed by gently blotting off with tissue paper. The experiments were run in duplicate and the present results are the average of the obtained values.

\section{Fatty Acid Analysis By Capillary Gas Liquid Chromatography}

Samples were placed in a $2 \mathrm{ml}$ vial for aliquots to be injected into the gas liquid chromatography. In this research, FAMES were separated by capillary gas liquid chromatography (Varian 3400) equipped with an auto sampler and a flame ionization detector (FID) using a $50 \mathrm{~m} \times 0.32 \mathrm{~mm}$ (I.D) fused silica bonded phase capillary column (BPX70, SGE, Melbourne, Australia).

Furthermore, Air was set at $60 \mathrm{psi}$ and hydrogen at $40 \mathrm{psi}$, along with helium, the carrier gas, at a pressure reading of about 70 $80 \mathrm{psi}$ and the column head pressure was adjusted to 30psi. In addition to that, the column oven was programmed from $160^{\circ} \mathrm{C}$ to $240^{\circ} \mathrm{C}$ at $5^{\circ} \mathrm{C} / \mathrm{min}$ and held for $4 \mathrm{~min}$. The oven temperature was then increased to $260^{\circ} \mathrm{C}$ at a rate of $8^{\circ} \mathrm{C} / \mathrm{min}$ and held for $6 \mathrm{~min}$. The injector and detector were maintained at $260^{\circ} \mathrm{C}$ and $300^{\circ} \mathrm{C}$ respectively.

Moreover, for each sample $2 \mu \mathrm{L}$ was injected using an SGE micro-syringe into the injector. The GC injection was split. Fatty acids were identified by comparison of retention times with those of standard mixtures of fatty acids methyl esters (GLC reference standard 403; Nu-Check Prep, Elysian, MN, USA). This result is achieved by comparing the retention times of each peak to the standard, injected under identical conditions. The report displaying the retention times, line up with the area counts, which are used to calculate the concentration of fatty acids.

\section{Experimental Design And Statistical Analysis}

Factorial designs were carried out using a completely randomized design (CRD) two factor (time and temperature) and three levels with two replications. ANOVA analysis of the results was carried out using SPSS software (version 11, 2004). Two way ANOVA was used to test for effect of time, temperature and interaction between time and temperature of the treatment where $p<0.05$ was considered statistically significant. Regression linear was used to develop the model, and the key plot software for making 3 dimensions using the sigma plot scientific graphing software.

\section{RESUlT AND DISCUSSION}

From the regression model equations, three dimensional surface plots were produced, using the sigma plot scientific graphing software. The three dimensional surface plots is shown in these below figures

Table 1. Regression model for frying performances of blanched potato

\begin{tabular}{lcc}
\hline Parameter & Regression Model & $\mathbf{R}^{2}$ \\
\hline Moisture & $41.18-9.82 \mathrm{X}_{1}+0.54 \mathrm{X}_{2}-$ & 0.87 \\
Loss & $0.04 \mathrm{X}_{1} \mathrm{X}_{2}+\mathrm{E}$ \\
\hline Fat Uptake & $25.60-1.81 \mathrm{X}_{1}-0.01 \mathrm{X}_{2}+$ & 0.78 \\
\multicolumn{3}{c}{$0.02 \mathrm{X}_{1} \mathrm{X}_{2}+\mathrm{E}$} \\
\hline Colour & $77.13+2.89 \mathrm{X}_{1}-0.07 \mathrm{X}_{2}-$ & 0.88 \\
\multicolumn{3}{c}{$0.03 \mathrm{X}_{1} \mathrm{X}_{2}+\mathrm{E}$} \\
\hline
\end{tabular}

The three dimensional surface plots is shown in these below figures

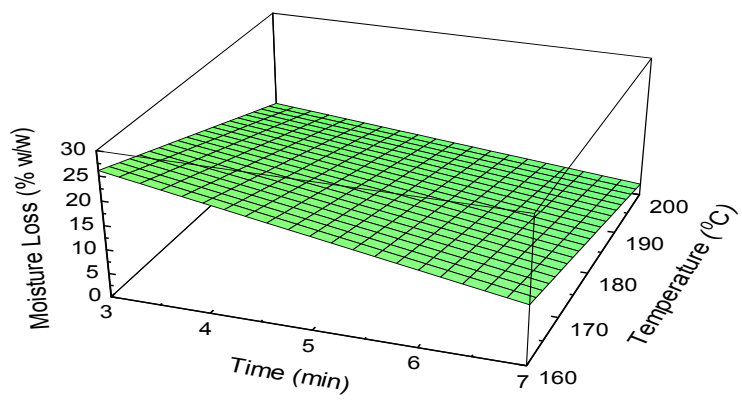

Figure 1. Moisture loss profile of blanched deep fat fried potato chips as influence by time $(\mathrm{t})$ and temperature $(\mathrm{T})$ 


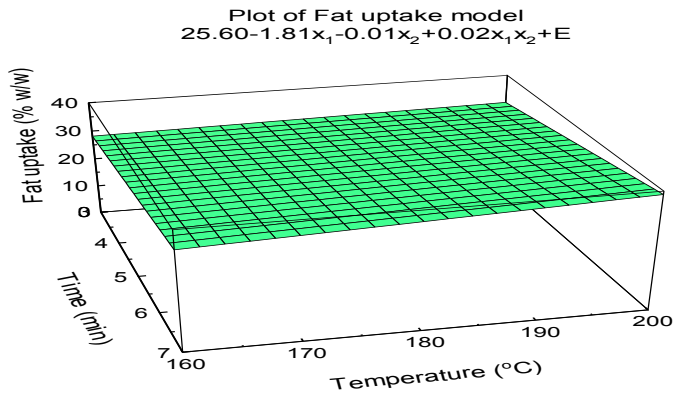

Figure 2. Fat uptake profile of blanched deep fat fried potato chips as influence by time $(\mathrm{t})$ and temperature $(\mathrm{T})$

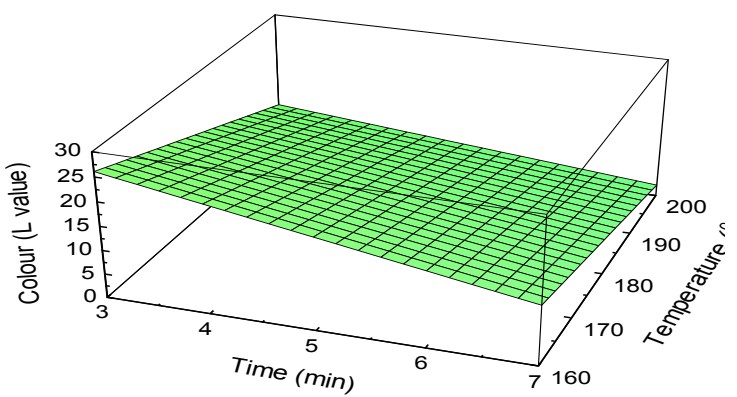

Figure 3. Colour profile of blanched deep fat fried potato chips as influence by time (t) and temperature $(\mathrm{T})$

\section{Fatty acids Profiles of sunflower}

Fatty acids profiles of the fried oil samples taken after 0 minute (fresh oil), 10 times of frying (150 $\mathrm{min}), 20$ times of frying (300 minutes )and 30 times of frying (450 minutes) are presented in following figures below.

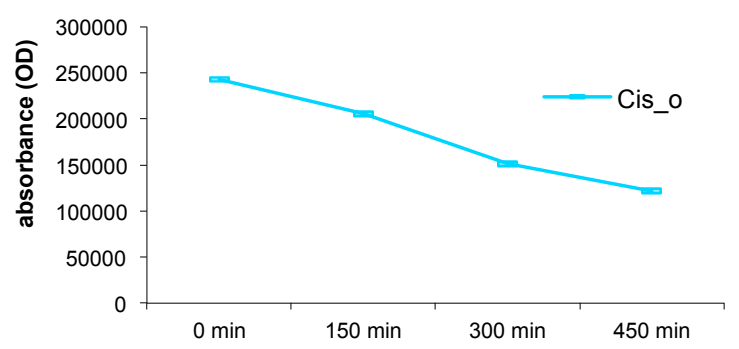

Frying time (Min)

Figure 4. The effect of frying time on the cis oleic content of fried oil

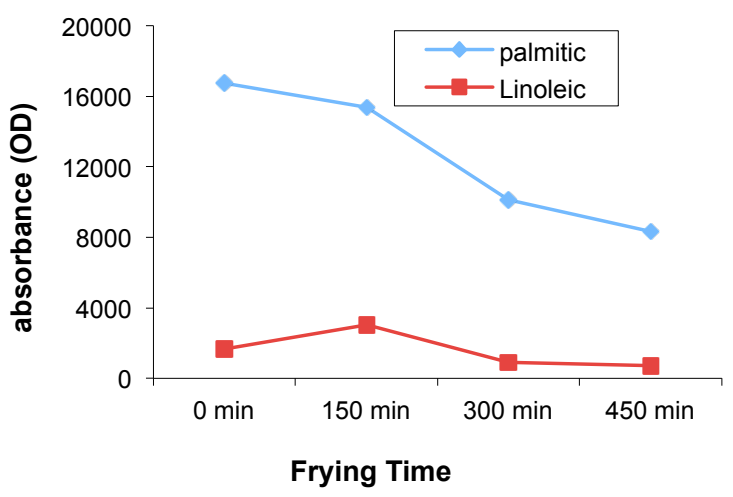

Figure 5. The effect of frying time on the palmitic and linoleic content of fried oil

From the figure it can be seen that as frying hours prolonged, there was a decrease in the relative percentage of oleic and linoleic acid. Researcher also found similar results that the percentage of unsaturated fatty acids tended to decrease, whereas the percentage of saturated fatty acid increased when they used high oleic sunflower oil for frying [7][8]. These investigators suggested that the reason for such change probably due to degradation of the unsaturated fatty acids. In this research project oleic acid was detected as majority used fried oil samples.

The percentage of the cis-oleic gradually decrease with the hours of frying. The similar trends also fond in the other unsaturated fatty acids linoleic which is decrease with hour of frying. Palmitic acid increased after 150 minutes of frying, however than decreased with the hours of frying increased. One of the most crucial factors determining the oxidative stability of oils is fatty acids composition. This is because of the reactions occurring between oils and substance under the continuous heating fatty acids profile changed during frying food proces. Moreover, According to FFAs content in deep-fried oils and French fries fluctuated during the frying process. It was in line with the study carried out by Arroyo et al. (1992), [9] in which the correlation between FFAs content in polar fractions and the number of frying was investigated. Deep-frying also causes thermal oxidation that leads to changes in the fatty acid composition of oil and development of peroxides [10] 


\section{Declaration of interests}

The authors declare that they have no known competing financial interests or personal relationships that could have appeared to influence the work reported in this paper.

\section{CONCLUSION}

It can be concluded that unsaturated fatty acids especially cis oleic and linoleic decreased rapidly after a long period of frying. The frying time and temperature also have an significant effect on the moisture content, fat uptake, moisture loss, colour and texture characteristic of blanched potato chips.

\section{REFERENCES}

[1] Hosseini, H., Ghorbani, M., Meshginfar, N., \& Mahoonak, A. S. (2016). A review on frying: Procedure, fat, deterioration progress and health hazards. Journal of the American Oil Chemists' Society, 93, 445466. http://dx.doi.org/10.1007/s11746016-2791-z.

[2] Mehta, U., \& Swinburn, B. (2001). A review of factors a.ecting fat absorption in hot chips. Critical Reviews in Food Science and Nutrition, 41(2), 133-154

[3] Camire, M. E., Kubow, S., \& Donnelly, D. J. (2009). Potatoes and human health. Critical Reviews in Food Science and Nutrition, $\quad 49, \quad 823-840$. http://dx.doi.org/10.1080/ 10408390903041996.

[4] Decker, E. A., \& Ferruzzi, M. G. (2013). Innovations in food chemistry and processing to enhance the nutrient profile of the white potato in all forms. Advances in Nutrition, 4, 345S-350S. http://dx.doi.org/10.3945/an.112.003574.

[5] Gillingham, L. G., Harris-Janz, S., \& Jones, P. J. H. (2011). Dietary monounsaturated fatty acids are protective against metabolic syndrome and cardiovascular disease risk factors. Lipids, 46(3), 209-228. http://dx.doi.org/10.1007/s11745-0103524-y.

[7] Melton, S.L., S. Jafar, D. Sykes and M. K. Tigriano. 1994. Review of stability measurements for frying oils and fried food flavor. J. Am. Oil Chem. Soc. 71, 1301- 1308.

[8] Moreira, R. G., Sun, X., \& Chen, Y. (1997). Factors affecting oil uptake in tortilla chips in deep fat frying. Journal of Food Engineering, 31(4), 485-498.

[9] Arroyo, R., Cuesta, C., Garrido-Polonio, G., López-Varela, S., \& Sónchez-Muniz, F. J. (1992). High-performance sizeexclusion chromatographic studies on polar components formed in sunflower oil used for frying. Journal of the American Oil Chemists' Society, 69(6), 557-563.

[10] Wang, S.-N., Sui, X.-N., Wang, Z.-J., Qi, B.-K., Jiang, L.-Z., Li, Y., \& Wei, X. (2016). Improvement in thermal stability of soybean oil by blending with camellia oil during deep fat frying. European Journal of Lipid Science and Technology, 118(4), 524-531. 